\title{
STUDI GEOKIMIA ENDAPAN SUNGAI AKTIF UNTUK MENDELINEASI AREA PROSPEK MINERALISASI LOGAM DI BAGIAN SELATAN KABUPATEN BLITAR, PROVINSI JAWA TIMUR
}

\section{GEOCHEMICAL STUDY OF ACTIVE STREAM SEDIMENTS TO DELINEATE MINERALISATION PROSPECT AREA IN THE SOUTH PART OF BLITAR REGENCY, EAST JAVA PROVINCE}

\author{
Calvin Nanda Suratman ${ }^{1}$, Bambang Priadi ${ }^{1}$, Sulaeman $^{2}$, \\ dan Hartaja Muhamad Hatta W. ${ }^{2}$ \\ 1Jurusan Teknik Geologi, Fakultas IImu dan Teknologi Kebumian, Institut Teknologi Bandung \\ ${ }^{2}$ Pusat Sumber Daya Mineral, Batubara dan Panas Bumi, Badan Geologi \\ calvinanda2805@gmail.com
}

\section{ABSTRAK}

Daerah penelitian secara administratif terletak di Kabupaten Blitar, Provinsi Jawa Timur. Secara geografis, daerah penelitian terletak pada koordinat $112^{\circ} 05^{\prime} 09^{\prime \prime}-112^{\circ} 15^{\prime} 45^{\prime \prime}$ Bujur Timur dan 8'11'53"- 8'18'47" Lintang Selatan atau 619625 - $639039 \mathrm{mT}$ dan 9080860 $9093645 \mathrm{mU}$ zona $49 \mathrm{~S}$ datum WGS1984 dengan luas $248,5 \mathrm{~km}^{2}$.

Menurut pembagian zona fisiografi Jawa Timur, daerah penelitian termasuk ke dalam Zona Pegunungan Selatan yang memiliki potensi mineral logam mulia dan logam dasar. Stratigrafi daerah penelitian berdasarkan literatur dari tua ke muda terdiri dari 6 satuan batuan, yaitu Formasi Mandalika, Formasi Campurdarat, Batuan Terobosan, Formasi Nampol, Formasi Wonosari, dan Aluvium.

Penelitian bertujuan untuk mendelineasi area prospek mineralisasi logam dengan menganalisis hubungan antara geologi dengan geokimia daerah penelitian. Data geokimia yang dianalisis pada penelitian ini berupa data kandungan unsur $\mathrm{Ag}, \mathrm{Mo}, \mathrm{Pb}, \mathrm{Zn}, \mathrm{Mn}, \mathrm{Cu}$, $\mathrm{Au}$, dan As dari contoh endapan sungai aktif. Analisis Geokimia dilakukan ke dalam dua tahap yaitu analisis univariat yang bertujuan untuk menentukan nilai ambang unsur dan analisis multivariat yang bertujuan untuk menentukan kelompok asosiasi unsur.

Analisis univariat yang dilakukan menghasilkan nilai ambang unsur sebagai berikut; $\mathrm{Ag} \mathrm{0,06}$ ppm, Mo 5,89 ppm, Pb 17,8 ppm, Zn 232 ppm, Mn 2.883 ppm, Cu 77 ppm, Au 0,0733 ppm, dan As $31 \mathrm{ppm}$. Sedangkan hasil analisis multivariat menunjukkan terdapat dua kelompok asosiasi unsur pada daerah penelitian, yaitu; $\mathrm{Ag}-\mathrm{Mo}-\mathrm{Pb}$ dan $\mathrm{Zn}-\mathrm{Mn}-\mathrm{Cu}-\mathrm{Au}-\mathrm{As}$. Tipe mineralisasi pada daerah penelitian yang diperoleh dari asosiasi unsur tersebut adalah tipe Carlin dan tipe epitermal. Hasil analisis geokimia kemudian dihubungkan dengan kondisi geologi daerah penelitian sehingga dapat ditentukan area prospek. Area prospek pada daerah penelitian ini terbagi ke dalam tiga kelompok yaitu, area prospek $\mathrm{Ag}-\mathrm{Mo}-\mathrm{Pb}$ yang terletak di hulu sungai pada daerah Ngrejo, Pasiraman, Kalibawang, Centung, Besole, dan Sumberglagah; area prospek Zn-Mn-Au-As yang terletak di hulu sungai pada daerah Sumberboto, Kepek, dan Sumberwringin; serta area prospek $\mathrm{Cu}$ yang terletak pada sungai di daerah Centung.

Kata kunci: Kabupaten Blitar, Geokimia, Endapan Sungai Aktif, Anomali, Asosiasi Unsur

\section{ABSTRACT}

The research area administratively located in Blitar Regency, East Java Province. Based on UTM coordinates, it is located at $112^{\circ} 05^{\prime} 09^{\prime \prime}-112^{\circ} 15^{\prime} 45^{\prime \prime}$ East Longitude and $8^{\circ} 11^{\prime} 53^{\prime \prime}-$ $8^{\circ} 18^{\prime} 47^{\prime \prime}$ South Latitude or 619625 - $639039 \mathrm{mE}$ and 9080860 - $9093645 \mathrm{mU}$ zone $49 \mathrm{~S}$ datum WGS1984, with research area of $248.5 \mathrm{~km}^{2}$. 
According to the East Java's physiographic zone, the research area is part of the East Java Southerns Mountain Zone which has the potential of preserving precious metal and base metal minerals. Stratigraphy of the research area based on literature from old to young consists of 6 units, namely Mandalika Formation, Campurdarat Formation, Intrusion Rocks, Nampol Formation, Wonosari Formation, and Alluvium.

The study aims to delineate metallic mineralisation prospect areas by analyzing the relationship between geology and geochemistry of the research area. The geochemical data analyzed consists of concentration dataset of Ag, Mo, Pb, Zn, Mn, Cu, Au and As elements from stream deposit samples. Geochemical analysis is carried out in two stages which are univariate analysis, aimed to determine the element threshold values and multivariate analysis, aimed to determine the element association groups.

Univariate analysis carried out produces element threshold values as follows; $\mathrm{Ag}$ is 0.06 ppm, Mo at $5.89 \mathrm{ppm}, \mathrm{Pb}$ is $17.8 \mathrm{ppm}, \mathrm{Zn}$ is $232 \mathrm{ppm}, \mathrm{Mn}$ is 2,883 ppm, $\mathrm{Cu}$ is $77 \mathrm{ppm}$, Au is $0.0733 \mathrm{ppm}$ and As is $31 \mathrm{ppm}$. While the results of multivariate analysis show that there are two main groups of elemental associations in the research area, namely; $\mathrm{Ag}-\mathrm{Mo}-\mathrm{Pb}$ and $\mathrm{ZnMn-Cu-Au-As.} \mathrm{The} \mathrm{mineralization} \mathrm{types} \mathrm{in} \mathrm{the} \mathrm{research} \mathrm{area} \mathrm{which} \mathrm{obtained} \mathrm{from} \mathrm{that}$ elemental association groups are Carlin Type and Epithermal. The relation between the results of geochemical analysis and the geological conditions of the research area are being used to determine the prospect area. The prospect area in this research area is divided into three groups, namely; the Ag-Mo-Pb prospect area which is located on upstream of Ngrejo, Pasiraman, Kalibawang, Centung, Besole, and Sumberglagah areas; the Zn-Mn-Au-As prospect area which is located on upstream of Sumberboto, Kepek and Sumberwringin areas; and the Cu prospect area which is located on stream of Centung area.

Keywords: Blitar Regency, Geochemistry, Active Stream Sediments, Anomaly, Elements Association

\section{PENDAHULUAN}

Daerah penelitian terletak di bagian selatan Kabupaten Blitar dengan iklim tropis sehingga memiliki tingkat pelapukan batuan yang tinggi. Hal ini menyebabkan singkapan batuan yang termineralisasi ditutupi oleh tanah tebal sehingga sulit diamati secara langsung. Pengambilan conto endapan sungai aktif dapat menjadi alternatif salah satu metode eksplorasi mineral logam yang berkaitan dengan cebakan bijih.

Bagian selatan Kabupaten Blitar merupakan bagian dari Zona Pegunungan Selatan Bagian Timur yang memiliki potensi mineral logam mulia dan logam dasar (van Bemmelen, 1949). Oleh karena itu, penulis tertarik untuk melakukan studi geokimia endapan sungai aktif di bagian selatan Kabupaten Blitar, Provinsi Jawa Timur untuk dapat mendelineasi area prospek potensi mineralisasi logam yang dilakukan dengan menginterpretasi hubungan antara pola persebaran anomali dan asosiasi unsur logam dengan kondisi geologi daerah penelitian.

Daerah penelitian secara administratif terletak di Kecamatan Wonotirto, Kabupaten Blitar, Provinsi Jawa Timur. Sedangkan secara geografis terletak pada koordinat $112^{\circ} 05^{\prime} 09^{\prime \prime}$ - $112^{\circ} 15^{\prime} 45^{\prime \prime}$ Bujur Timur dan 8'11'53" - 8'18'47" Lintang Selatan atau $9080860 \mathrm{mU}$ s.d. 9093645 $\mathrm{mU}$ dan $619625 \mathrm{mT}$ s.d. $639039 \mathrm{mT}$ zona 49S datum WGS 1984 dengan luas 248,5 $\mathrm{km}^{2}$ (Gambar 1).

Hasil penelitian sebelumnya oleh Widodo dan Simanjuntak (2002) menyatakan bahwa indikasi mineralisasi yang ditemukan di daerah penelitian adalah adanya anomali unsur $\mathrm{Au}$ dan $\mathrm{Hg}$ dari conto sedimen sungai, dan ubahan batuan didominasi oleh argilik - argilik lanjut, serta hasil analisis kimia batuan menunjukkan kandungan $2.081 \mathrm{ppm}$ s.d.2.555 ppm Hg, 4950 ppb Au dan $2,767 \%$ Cu. 


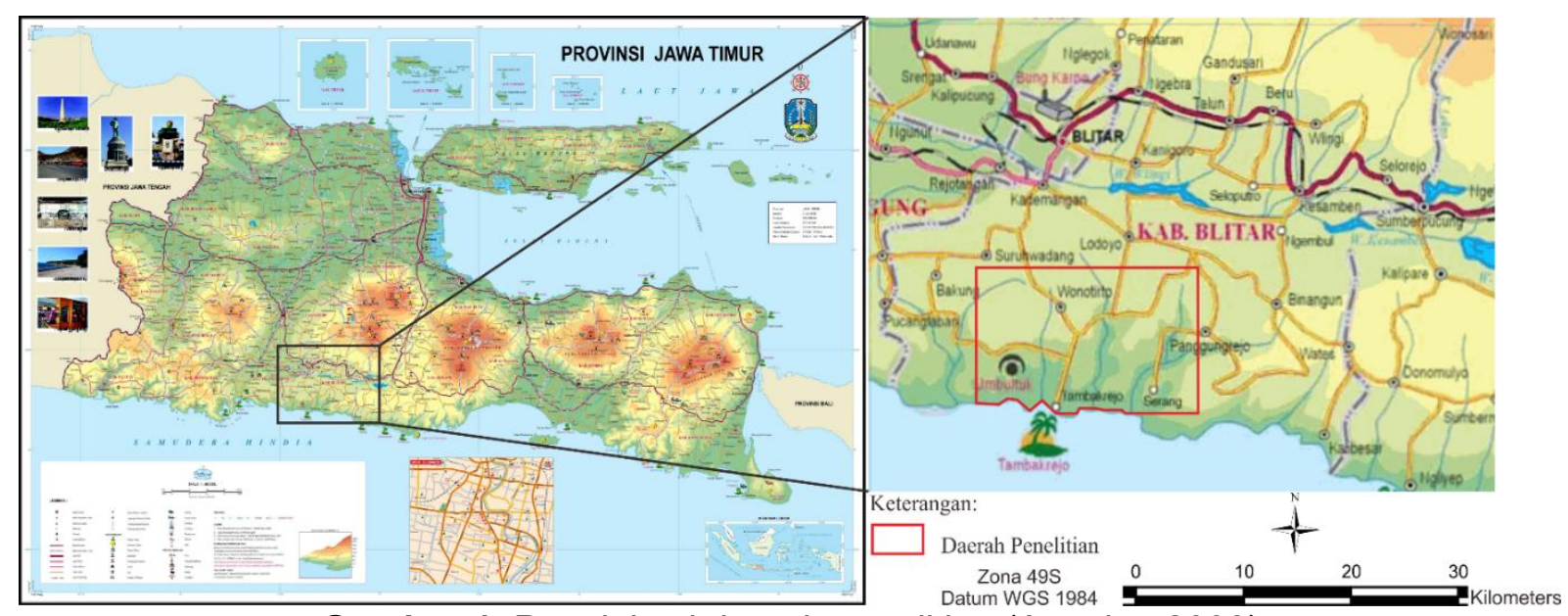

Gambar 1. Peta lokasi daerah penelitian (Anonim, 2003)

\section{GEOLOGI DAERAH PENELITIAN}

Daerah penelitian berada di Jawa Timur yang secara fisiografi dapat dibagi menjadi tujuh zona dari utara ke selatan, yaitu Zona Rembang, Dataran Aluvial Jawa Utara, Zona Randublatung, Zona Kendeng, Zona Depresi Tengah Bagian Timur, Gunungapi Kuarter, dan Zona Pegunungan Selatan Bagian Timur. Daerah penelitan berada di Zona Pegunungan Selatan Bagian Timur. (van Bemmelen, 1949).

Stratigrafi regional daerah penelitian berurutan dari tua ke muda tersusun atas 6 satuan batuan (Sjarifudin dan Hamidi, 1992), yaitu Formasi Mandalika (Tomm), Formasi Campurdarat (Tmcl), Satuan Batuan Terobosan (Tomi), Formasi Nampol (Tmn), Formasi Wonosari (Tmwl), dan Aluvium (Qa). Struktur regional bagian selatan Kabupaten Blitar memperlihatkan empat pola struktur utama yang berkembang, yaitu struktur yang berarah timurlaut-baratdaya, baratlaut-tenggara, utara-selatan dan timurbarat (Gambar 2 dan Gambar 3) (Sjarifudin dan Hamidi, 1992).

Daerah penelitian terletak di Jawa timur yang dapat dibagi dalam lima provinsi tektonik dari utara ke selatan, yaitu lereng regional bagian utara terdiri dari Paparan Kontinen Stabil Rembang, Zona Transisi Randublatung, Punggungan Kendeng yang merupakan perpanjangan
Punggungan Bogor ke arah timur, Busur Gunungapi Kuarter, dan lereng regional bagian selatan yang merupakan area pengangkatan membentuk Busur Gunungapi Tersier atau Zona Pegunungan Selatan Bagian Timur (Darman dan Sidi, 2000).

Dari hasil analisis pola aliran sungai, daerah penelitian memiliki pola aliran sungai dendritrik. Pola dendritik dicirikan dengan kenampakan bercabang menyerupai ranting pohon, dikontrol oleh faktor resistensi batuan yang relatif seragam dan lereng dengan kemiringan terjal (Howard, 1967).

\section{METODE}

Metode yang digunakan dalam penelitian ini meliputi analisis geokimia unsur logam dan analisis statistik.

Analisis geokimia unsur logam dilakukan menggunakan metode Atomic Absorbtion Spectrometry (AAS) dan Induced Coupled Plasma-Mass Spectrometer (ICP-MS) yang dilakukan oleh Laboratorium Kimia Mineral Pusat Sumber Daya Mineral Batubara dan Panas Bumi (PSDMBP) terhadap 119 conto endapan sungai aktif. Adapun unsur-unsur yang dianalisis, yaitu Ag-Mo-Pb-Zn-Mn-Cu-Au-As.

Data kandungan unsur logam kemudian diolah dengan metode analisis statistik, yaitu analisis univariat dan multivariat. 


\section{MAKALAH ILMIAH}

Analisis univariat dilakukan untuk mengetahui nilai ambang unsur, sedangkan analisis multivariat dilakukan untuk mengetahui kelompok asosiasi unsur. Nilai ambang unsur dan kelompok asosiasi unsur selanjutnya dihubungkan dengan kondisi geologi daerah penelitian untuk mendelineasi area prospek yang mempunyai potensi ekonomis mineralisasi logam.

\section{Analisis Univariat}

Analisis univariat yang digunakan pada penelitian ini, yaitu Metode Simpangan Baku dan Metode Kurva Probabilitas.

\section{Metode Simpangan Baku}

Metode Simpangan Baku adalah metode penentuan nilai ambang dengan menggunakan parameter rata-rata (Suroto, 2005). Simpangan baku adalah gambaran penyebaran nilai-nilai dari data geokimia (Sinclair, 1987). Semakin besar nilai simpangan baku mencerminkan data yang dianalisis semakin tersebar heterogen dari nilai rata-rata data tersebut. Metode ini hanya digunakan pada data kandungan unsur yang terdistribusi normal. Nilai ambang yang didapat dari Metode Simpangan Baku memiliki nilai sebesar 2,5\% (Rose dkk. 1979).

$$
S D=\sqrt{\sum_{i=1}^{n}\left(x-x_{i}\right)^{2} /(n-1)}
$$

Nilai Ambang $=\bar{x}+2 \mathrm{SD}$

\section{keterangan:}

$\mathrm{SD}=$ standar deviasi/ simpangan baku

$\bar{x}=$ rata-rata

$x_{i}=$ data ke $\mathrm{i}$

$\mathrm{n}=$ jumlah data

\section{Metode Kurva Probabilitas}

Metode ini merupakan metode yang digunakan dalam penentuan nilai ambang suatu unsur dengan cara membuat kurva probabilitas. Nilai ambang yang didapat digunakan untuk memisahkan data menjadi populasi anomali dan populasi latar belakang. Metode ini hanya digunakan pada data kandungan unsur yang yang tidak terdistribusi normal. Untuk mengeplot data ke dalam grafik probabilitas, sebelumnya data harus diubah ke dalam nilai logaritma. Nilai ambang yang didapat dari Metode Kurva Probabilitas memiliki nilai sebesar 2,5\% (Rose dkk., 1979).
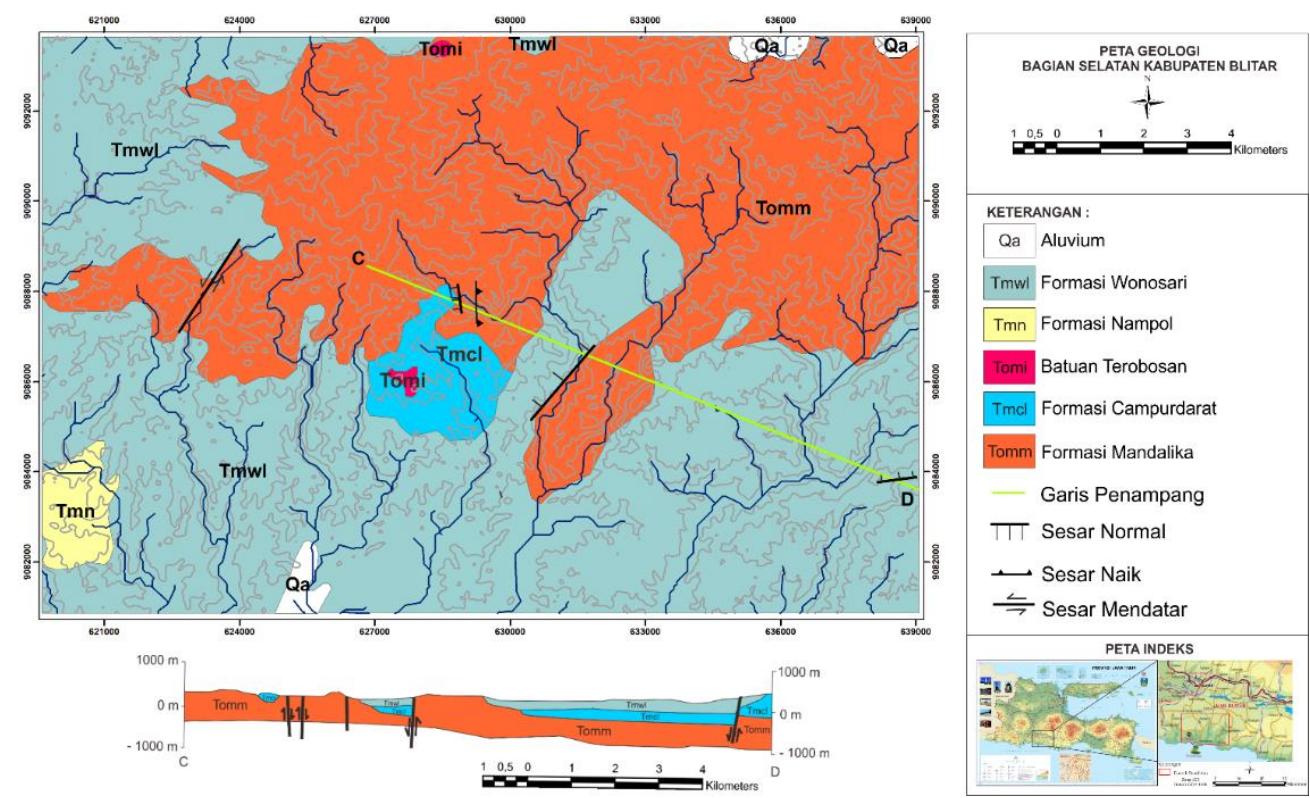

Gambar 2. Peta dan penampang geologi regional bagian selatan Kabupaten Blitar (digambar ulang dari Sjarifudin dan Hamidi, 1992) 


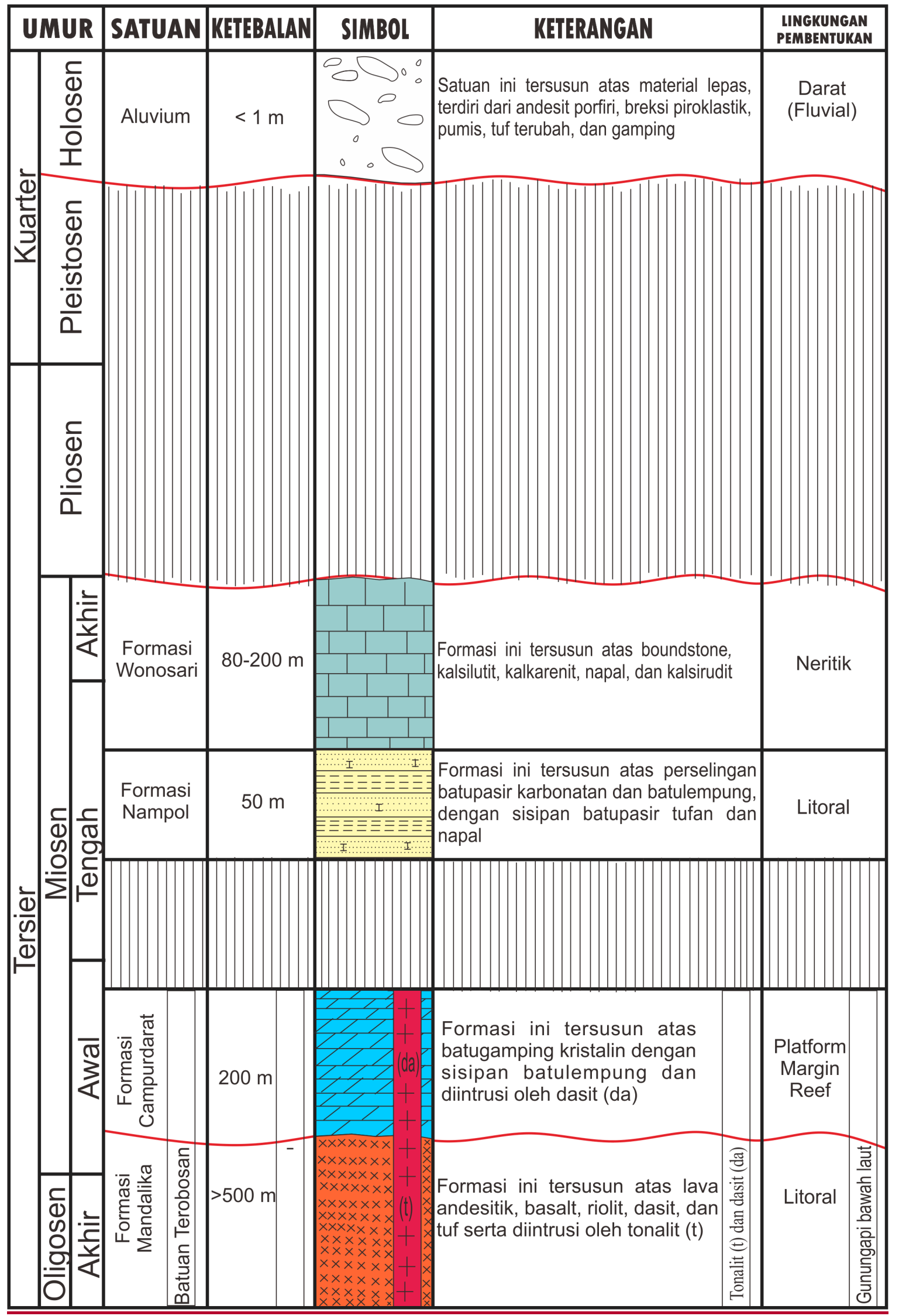

Gambar 3. Kolom stratigrafi regional bagian selatan Kabupaten Blitar

(diadaptasi dari Sjarifudin dan Hamidi, 1992) 


\section{Analisis Multivariat}

Analisis multivariat yang digunakan pada penelitian ini, yaitu Metode Persentil dan Pengelompokan Hierarki.

\section{Metode Persentil}

Metode persentil dilakukan dengan melihat pola kandungan dari data unsur dengan memilih beberapa nilai tertinggi pada persentil tertentu (Surjadi, 1976). Nilai persentil berkisar dari 0 hingga 100. Misal untuk persentil 90 (P90), maka nilai konsentrasi tertinggi yang diambil adalah $10 \%$ dari jumlah data.

\section{Metode Pengelompokan Hierarki}

Pengelompokan hierarki merupakan metode kluster yang mengelompokkan data secara berurutan berdasarkan kemiripan korelasinya (Karypis dkk., 1999). Pada metode ini setiap unsur dianggap sebagai satu variabel yang terpisah. Variabel-variabel tersebut kemudian digabungkan berdasarkan kemiripan secara berurutan hingga menjadi satu kelompok atau kluster yang besar. Hasil dari analisis digambarkan dengan diagram pohon untuk menunjukkan kluster atau kelompok asosiasi unsur. Tingkat asosiasi antar unsur digambarkan oleh letak garis penghubung, semakin ke bawah garis penghubung berarti semakin kuat asosiasi antar unsur tersebut.

\section{HASIL DAN ANALISIS}

Data yang akan diolah secara statistik berupa hasil analisis geokimia unsur logam dari 119 conto endapan sungai aktif. Adapun unsur-unsur yang diolah dalam penelitian ini meliputi $\mathrm{Ag}-\mathrm{Mo}-\mathrm{Pb}-$ $\mathrm{Zn}-\mathrm{Mn}-\mathrm{Cu}-\mathrm{Au}-\mathrm{As}$ dalam satuan ppm Ketelitian data kandungan tiap unsur conto endapan sungai aktif berbeda, unsur $\mathrm{Ag}$ dan unsur Mo memiliki dua angka di belakang koma; $\mathrm{Pb}, \mathrm{Cu}$, As memiliki satu angka di belakang koma; dan Au memiliki empat angka di belakang koma.

\section{Analisis Univariat}

Analisis univariat bertujuan untuk mendapatkan nilai ambang atau batas antara populasi anomali dan latar belakang.

\section{Metode Simpangan Baku}

Metode ini hanya digunakan pada data kandungan unsur yang terdistribusi normal, yaitu ketika nilai rata-rata lebih besar daripada nilai simpangan baku (Tabel 1). Adapun unsur-unsur yang terdistribusi normal, yaitu $\mathrm{Pb}, \mathrm{Zn}, \mathrm{Mn}$, dan $\mathrm{Cu}$. Berikut merupakan hasil penentuan nilai ambang dengan Metode Simpangan Baku:

Tabel 1. Hasil penentuan nilai ambang dengan Metode Simpangan Baku

\begin{tabular}{ccccc}
\hline No & Unsur & $\begin{array}{c}\text { Nilai } \\
\text { Rata- } \\
\text { rata } \\
\text { (ppm) }\end{array}$ & $\begin{array}{c}\text { Simpangan } \\
\text { Baku } \\
\text { (ppm) }\end{array}$ & $\begin{array}{c}\text { Nilai } \\
\text { Ambang } \\
\text { (ppm) }\end{array}$ \\
\hline 1 & $\mathrm{Ag}$ & 0,01 & 0,06 & - \\
\hline 2 & $\mathrm{Mo}$ & 1,26 & 1,80 & - \\
\hline 3 & $\mathrm{~Pb}$ & 9,9 & 4,0 & 17,8 \\
\hline 4 & $\mathrm{Zn}$ & 128 & 52 & 232 \\
\hline 5 & $\mathrm{Mn}$ & 1.802 & 540 & 2.883 \\
\hline 6 & $\mathrm{Cu}$ & 51,0 & 13,0 & 77,0 \\
\hline 7 & $\mathrm{Au}$ & 0,0074 & 0,0282 & - \\
\hline 8 & $\mathrm{As}$ & 10,6 & 10,9 & - \\
\hline
\end{tabular}

\section{Metode Kurva Probabilitas}

Metode ini hanya digunakan pada data kandungan unsur yang tidak terdistribusi normal-yaitu Ag, Mo, Au, dan As (Tabel 2). Pada penentuan nilai ambang dengan metode ini dihasilkan dua nilai ambang, yaitu nilai ambang 1 dan nilai ambang 2 . Nilai ambang 1 memiliki nilai yang lebih tinggi dibandingkan nilai ambang 2 . Berikut merupakan hasil penentuan nilai ambang dengan Metode Kurva Probabilitas:

Tabel 2. Hasil penentuan nilai ambang dengan Metode Kurva Probabilitas

\begin{tabular}{cccc}
\hline \multirow{2}{*}{ No } & \multirow{2}{*}{ Unsur } & \multicolumn{2}{c}{ Nilai Ambang (ppm) } \\
\cline { 3 - 4 } & & \multicolumn{2}{c}{ Kurva Probabilitas } \\
\cline { 3 - 4 } & $\mathrm{Ag}$ & $\mathbf{1}$ & $\mathbf{2}$ \\
\hline 1 & $\mathrm{Mo}$ & 5,06 & 0,02 \\
\hline 2 & $\mathrm{Au}$ & 0,0733 & 1,82 \\
\hline 3 & $\mathrm{As}$ & 31,0 & 0,0014 \\
\hline 4 & & & 4,4 \\
\hline
\end{tabular}




\section{Penentuan Nilai Ambang}

Nilai ambang yang telah didapat dari Metode Simpangan Baku dan Kurva Probabilitas kemudian dibandingkan dibandingkan dengan nilai kandungan rata-rata tiap unsur di dalam kerak bumi/nilai latar belakang regional menurut Rose dkk. (1979). Hal ini dilakukan untuk menghasilkan nilai ambang akhir yang paling baik (Tabel 3).

\section{Analisis Multivariat}

Analisis Multivariat bertujuan untuk menentukan kelompok asosiasi unsur berdasarkan tingkat kekerabatan antar unsur.

\section{Metode Persentil}

Metode ini digunakan untuk menentukan kelompok asosiasi unsur dengan melihat konsentrasi tinggi pada persentil tertentu. Suatu unsur dapat dikatakan berasosiasi dengan unsur lainnya apabila konsentrasi tinggi pada unsur tersebut mencapai setengah atau lebih dari jumlah konsentrasi unsur tersebut pada persentil tertentu. Berikut merupakan tingkat asosiasi antar unsur yang dihasilkan dari Metode Persentil:

Warna menunjukkan pada persentil berapa kedua unsur berasosiasi. Warna hijau menunjukkan persentil 90, jingga menunjukkan persentil 85, dan kuning menunjukkan persentil 80. Tabel di bawah menunjukkan adanya dua asosiasi unsur, yaitu $\mathbf{P b}-\mathbf{M o}-\mathbf{A g}$ dan $\mathbf{Z n - M n}$ (Tabel 4).

\section{Metode Pengelompokan Hierarki}

Metode ini digunakan untuk menentukan kelompok asosiasi unsur dengan menghitung nilai kemiripan antar unsur. Penghitungan dilakukan dengan Metode Ward Linkage. Hasil dari analisis digambarkan dengan diagram pohon untuk menunjukkan kluster atau kelompok asosiasi unsur (Gambar 4). Tingkat asosiasi antar unsur digambarkan oleh letak garis penghubung, semakin ke bawah garis penghubung berarti semakin kuat asosiasi antar unsur tersebut.

Tabel 3. Hasil penentuan nilai ambang akhir

\begin{tabular}{|c|c|c|c|c|c|c|c|}
\hline \multirow{3}{*}{ No } & \multirow{3}{*}{ Unsur } & \multicolumn{3}{|c|}{ Nilai Ambang (ppm) } & \multirow{3}{*}{$\begin{array}{l}\text { Nilai Latar } \\
\text { Belakang } 1 \\
\text { Regional } \\
\text { (ppm) }\end{array}$} & \multicolumn{2}{|c|}{$\begin{array}{l}\text { Nilai Ambang } \\
\text { (ppm) }\end{array}$} \\
\hline & & \multirow{2}{*}{$\begin{array}{c}\text { Simpangan } \\
\text { Baku }\end{array}$} & \multicolumn{2}{|c|}{ Kurva Probabilitas } & & & \\
\hline & & & 1 & 2 & & 1 & 2 \\
\hline 1 & $\mathrm{Ag}$ & - & 0,06 & 0,02 & 0,05 & 0,06 & - \\
\hline 2 & Mo & - & 5,89 & 1,82 & 1,50 & 5,89 & 1,82 \\
\hline 3 & $\mathrm{~Pb}$ & 17,8 & - & - & 10,0 & 17,8 & - \\
\hline 4 & $\mathrm{Zn}$ & 232 & - & - & 70 & 232 & - \\
\hline 5 & $\mathrm{Mn}$ & 2883 & - & - & 950 & 2883 & - \\
\hline 6 & $\mathrm{Cu}$ & 77,0 & - & - & 50,0 & 77,0 & - \\
\hline 7 & $\mathrm{Au}$ & - & 0,0733 & 0,0014 & 0,0030 & 0,0733 & - \\
\hline 8 & As & - & 32,0 & 4,4 & 2,0 & 31,0 & 4,5 \\
\hline
\end{tabular}

Tabel 4. Tingkat asosiasi antar unsur dengan Metode Persentil

\begin{tabular}{|c|c|c|c|c|c|c|c|c|}
\hline Unsur & $\mathrm{Ag}$ & Mo & $\mathrm{Pb}$ & $\mathrm{Cu}$ & As & $\mathrm{Zn}$ & $\mathrm{Mn}$ & $\mathrm{Au}$ \\
\hline $\mathrm{Ag}$ & & P90 & P90 & $\mathrm{X}$ & $\mathrm{X}$ & $\mathrm{X}$ & $\mathrm{X}$ & $\mathrm{X}$ \\
\hline Mo & & & $\overline{P 90}$ & $\bar{X}$ & $\bar{X}$ & $\bar{X}$ & $\bar{X}$ & $\mathrm{X}$ \\
\hline $\mathrm{Pb}$ & & & & $X$ & $\mathrm{X}$ & $X$ & $\mathrm{X}$ & $\mathrm{X}$ \\
\hline $\mathrm{Cu}$ & & & & & $\bar{X}$ & $\mathrm{X}$ & $\bar{X}$ & $\mathrm{X}$ \\
\hline As & & & & & & $\mathrm{X}$ & $\mathrm{X}$ & $\mathrm{X}$ \\
\hline $\mathrm{Zn}$ & & & & & & & P90 & $\mathrm{X}$ \\
\hline $\mathrm{Mn}$ & & & & & & & & $\mathrm{X}$ \\
\hline \multicolumn{9}{|c|}{$\mathrm{Au}$} \\
\hline \multicolumn{9}{|c|}{ Keterangan: } \\
\hline P90 & Perse & & & & & & & \\
\hline P85 & Perse & & & & & & & \\
\hline P80 & Perse & & & & & & & \\
\hline
\end{tabular}




\section{MAKALAH ILMIAH}

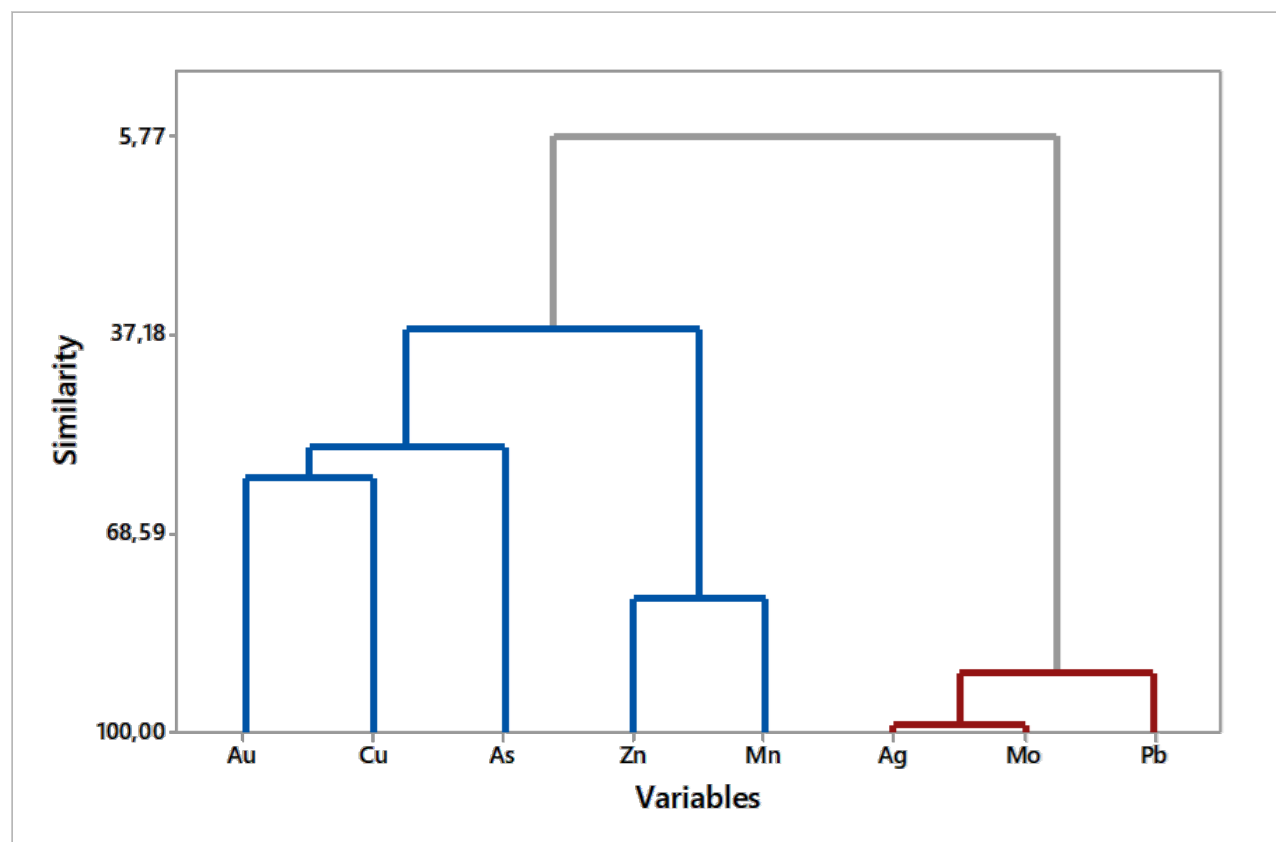

Gambar 4. Diagram pohon kelompok asosiasi unsur dengan Metode Pengelompokan Hierarki

Warna pada gambar 4 menunjukkan kluster atau asosiasi unsur. Warna merah menunjukkan asosiasi Ag-Mo-Pb dan biru menunjukkan asosiasi $\mathrm{Zn}-\mathrm{Mn}-\mathrm{Cu}-\mathrm{Au}-\mathrm{As}$.

\section{Penentuan Kelompok Asosiasi Unsur}

Kelompok asosiasi unsur yang telah didapat dari Metode Persentil dan Pengelompokan Hierarki kemudian dibandingkan (Tabel 5). Unsur-unsur yang muncul pada kedua metode tersebut dijadikan sebagai asosiasi akhir, sedangkan unsur yang hanya muncul di salah satu metode diberi tanda kurung yang menunjukkan bahwa unsur tersebut berasosiasi relatif lemah dengan unsurunsur lainnya dalam suatu asosiasi. Hal ini dilakukan untuk menghasilkan kelompok akhir asosiasi unsur yang lebih baik. Misalnya kelompok unsur yang didapat dari Metode Persentil adalah Zn-Mn, sedangkan kelompok unsur yang didapat dari Metode Pengelompokan Hierarki adalah Zn-Mn-Cu-Au-As. Kelompok akhir asosiasi unsur adalah $\mathbf{Z n - M n - ( C u ) - ( A u ) - ~}$ (As) yang ditunjukkan oleh unsur $\mathrm{Cu}, \mathrm{Au}$, As berasosiasi relatif lemah dengan $\mathrm{Zn}$ dan $\mathrm{Mn}$ dibandingkan asosiasi antara $\mathrm{Zn}$ dan $\mathrm{Mn}$ itu sendiri.
Tabel 5. Hasil penentuan kelompok akhir asosiasi unsur

\begin{tabular}{|c|c|c|c|c|}
\hline Metode & \multicolumn{2}{|c|}{$\begin{array}{c}\text { Kelompok } \\
\text { asosiasi } \\
\text { unsur }\end{array}$} & \multicolumn{2}{|c|}{$\begin{array}{l}\text { Kelompok akhir } \\
\text { asosiasi unsur }\end{array}$} \\
\hline Persentil & $\begin{array}{c}\text { Ag- } \\
\text { Mo-Pb }\end{array}$ & $\begin{array}{l}\mathrm{Zn}- \\
\mathrm{Mn}\end{array}$ & & Zn- \\
\hline $\begin{array}{l}\text { Pengelompokan } \\
\text { hierarki }\end{array}$ & $\begin{array}{c}\mathrm{Ag}- \\
\mathrm{Mo}-\mathrm{Pb}\end{array}$ & $\begin{array}{l}\mathrm{Zn}- \\
\mathrm{Mn}- \\
\mathrm{Cu}- \\
\mathrm{Au}- \\
\mathrm{As}\end{array}$ & $\begin{array}{c}\mathrm{Ag}- \\
\mathrm{Mo-} \mathrm{Pb}\end{array}$ & $\begin{array}{l}\mathrm{Mn}- \\
(\mathrm{Cu})- \\
(\mathrm{Au})- \\
\text { (As) }\end{array}$ \\
\hline
\end{tabular}

\section{PEMBAHASAN DAN INTERPRETASI DATA}

\section{Persebaran Anomali Unsur}

Data geokimia yang dianalisis pada penelitian ini berupa data kandungan unsur $\mathrm{Ag}$, Mo, $\mathrm{Pb}, \mathrm{Zn}, \mathrm{Mn}, \mathrm{Cu}$, Au, dan As dari conto endapan sungai aktif.

\section{Perak $[\mathrm{Ag}]$}

Unsur Ag memiliki nilai kandungan dengan rentang 0,01 ppm-0,68 ppm. Berdasarkan analisis univariat yang dilakukan, unsur $\mathrm{Ag}$ memiliki populasi anomali dengan nilai ambang sebesar 0,06 ppm. Populasi anomali unsur Ag terdapat pada Formasi Mandalika dan Formasi Wonosari. Unsur $\mathrm{Ag}$ berasosiasi dengan unsur $\mathrm{Pb}$ dan $\mathrm{Mo}$. 


\section{Molibdenum [Mo]}

Unsur Mo memiliki nilai kandungan dengan rentang 0,09 ppm-17,75 ppm. Berdasarkan analisis univariat yang dilakukan, unsur Mo memiliki populasi anomali dengan nilai ambang 1 sebesar 5,89 ppm dan nilai ambang 2 sebesar 1,82 ppm. Populasi anomali unsur Mo terdapat pada Formasi Mandalika dan Formasi Wonosari. Unsur Mo berasosiasi dengan unsur $\mathrm{Pb}$ dan $\mathrm{Ag}$.

\section{Timbal [Pb]}

Unsur $\mathrm{Pb}$ memiliki nilai kandungan dengan rentang 3,4 ppm-31,8 ppm. Berdasarkan analisis univariat yang dilakukan, unsur $\mathrm{Pb}$ memiliki populasi anomali dengan nilai ambang sebesar 17,8 ppm. Populasi anomali unsur $\mathrm{Pb}$ terdapat pada Formasi Mandalika dan Formasi Wonosari. Unsur $\mathrm{Pb}$ berasosiasi dengan unsur Mo dan $\mathrm{Ag}$.

\section{Seng $[\mathrm{Zn}]$}

Unsur Zn memiliki nilai kandungan dengan rentang 30 ppm-291 ppm. Berdasarkan analisis univariat yang dilakukan, unsur $\mathrm{Zn}$ memiliki populasi anomali dengan nilai ambang sebesar 232 ppm. Populasi anomali unsur Zn terdapat pada Formasi Mandalika dan Formasi Wonosari. Unsur $\mathrm{Zn}$ berasosiasi dengan $\mathrm{Cu}$, $\mathrm{As}, \mathrm{Au}$, dan $\mathrm{Mn}$.

\section{Mangan [Mn]}

Unsur Mn memiliki nilai kandungan dengan rentang 541 ppm-3720 ppm. Berdasarkan analisis univariat yang dilakukan, unsur $\mathrm{Mn}$ memiliki populasi anomali dengan nilai ambang 2883 ppm. Populasi anomali unsur Mn terdapat pada Formasi Mandalika dan Formasi Wonosari. Unsur $\mathrm{Mn}$ berasosiasi dengan $\mathrm{Cu}, \mathrm{As}, \mathrm{Au}$, dan Zn.

\section{Tembaga [Cu]}

Unsur $\mathrm{Cu}$ memiliki nilai kandungan dengan rentang 16,4 ppm-80,4 ppm.
Berdasarkan analisis univariat yang dilakukan, unsur $\mathrm{Cu}$ memiliki populasi anomali dengan nilai ambang sebesar 77,0 ppm. Populasi anomali unsur $\mathrm{Cu}$ hanya terdapat pada Formasi Wonosari. Unsur $\mathrm{Cu}$ berasosiasi dengan $\mathrm{As}, \mathrm{Au}, \mathrm{Zn}$, dan $\mathrm{Mn}$.

\section{Arsen [As]}

Unsur As memiliki nilai kandungan dengan rentang 1,3 ppm-70,0 ppm. Berdasarkan analisis univariat yang dilakukan, unsur As memiliki populasi anomali dengan nilai ambang 1 sebesar 31,0 ppm dan nilai ambang 2 sebesar 4,4 ppm. Populasi anomali unsur As terdapat pada Formasi Mandalika dan Formasi Wonosari. Unsur As berasosiasi dengan $\mathrm{Cu}, \mathrm{Au}, \mathrm{Zn}$, dan $\mathrm{Mn}$.

\section{Emas [Au]}

Unsur Au memiliki nilai kandungan dengan rentang 0,0005 ppm-0,2620 ppm. Berdasarkan analisis univariat yang dilakukan, unsur $\mathrm{Au}$ memiliki populasi anomali dengan nilai ambang sebesar $0,0733 \mathrm{ppm}$. Populasi anomali unsur Au terdapat pada Formasi Mandalika dan Formasi Wonosari. Unsur Au berasosiasi dengan $\mathrm{Cu}, \mathrm{As}, \mathrm{Zn}$, dan Mn.

\section{Persebaran Asosiasi Unsur}

Pengolahan data yang digunakan dalam analisis penentuan kelompok asosiasi unsur ialah Metode Persentil dan Metode Pengelompokan Hierarki. Kelompok asosiasi unsur yang terdapat pada daerah penelitian berdasarkan perpaduan dari kedua metode tersebut adalah $\mathbf{A g}-\mathbf{M o}-\mathbf{P b}$ dan $\mathbf{Z n - M n - ( C u ) - ( A u ) - ( A s ) . ~}$

Persebaran anomali unsur yang telah ditentukan kemudian dibandingkan secara spasial dengan persebaran satuan batuan (Gambar 5). Hal ini dilakukan untuk menginterpretasi hubungan antara persebaran asosiasi unsur dan kondisi geologi daerah penelitian. 


\section{MAKALAH ILMIAH}

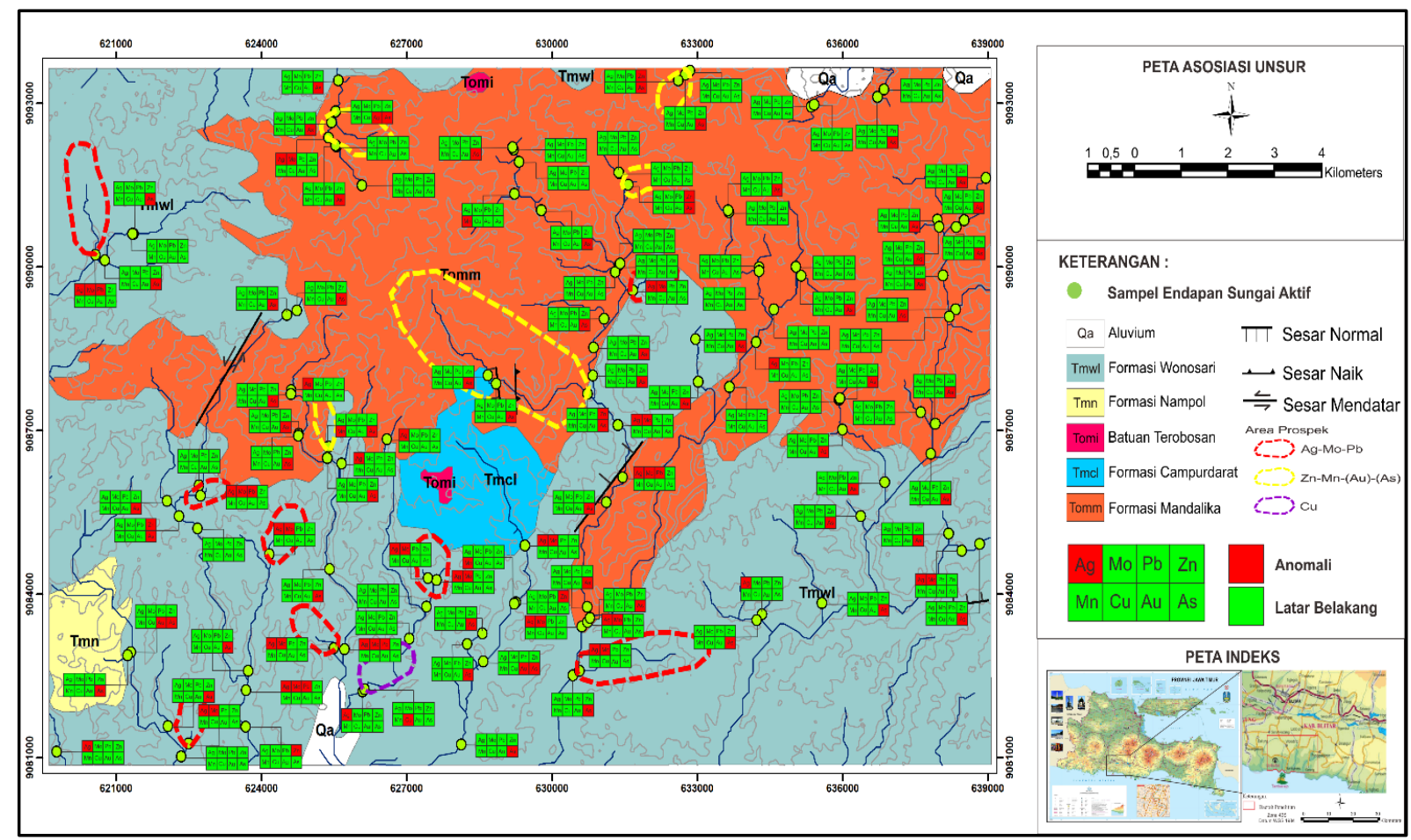

Gambar 5. Tumpang tindih peta asosiasi unsur dan geologi regional bagian selatan Kabupaten Blitar

Berdasarkan Gambar 5, maka dapat dinyatakan bahwa kemungkinan anomali dari asosiasi Ag-Mo-Pb memiliki hubungan yang kuat dengan Formasi Wonosari, sedangkan anomali dari asosiasi $\mathrm{Zn}-\mathrm{Mn}-(\mathrm{Au})-(\mathrm{As})$ kemungkinan memiliki hubungan yang kuat dengan Formasi Mandalika. Anomali unsur $\mathrm{Cu}$ terbentuk pada Formasi Wonosari sehingga diinterpretasikan memiliki pembentukan yang berbeda di dalam asosiasi $\mathrm{Zn}-\mathrm{Mn}-(\mathrm{Cu})-(\mathrm{Au})-(\mathrm{As})$.

\section{Tipe Mineralisasi}

Kelompok asosiasi unsur pada daerah penelitian kemudian dibandingkan dengan tipe-tipe mineralisasi menurut literatur yang ada (Tabel 6). Hal ini dilakukan untuk menginterpretasi tipe mineralisasi yang terjadi di daerah penelitian.

Warna pada Tabel 6 menunjukkan asosiasi unsur. Warna merah menunjukkan asosiasi $\mathrm{Ag}-\mathrm{Mo}-\mathrm{Pb}$ dan biru menunjukkan asosiasi $\mathrm{Zn}-\mathrm{Mn}-(\mathrm{Cu})-(\mathrm{Au})-$ (As).
Tabel 6. Perbandingan asosiasi unsur dengan tipe mineralisasi

\begin{tabular}{cl}
\hline Tipe Mineralisasi & \multicolumn{1}{c}{ Asosiasi Unsur } \\
\hline \multirow{2}{*}{ Orthomagmatik $^{1}$} & $\mathrm{PGE}(\mathrm{Ru}, \mathrm{Rh}, \mathrm{Pd}, \mathrm{Os}, \mathrm{Ir}$, \\
& $\mathrm{Pt}$ ), $\mathrm{Ni}, \mathrm{Cu}, \mathrm{V}, \mathrm{Ti}, \mathrm{Cr}, \mathrm{Fe}$ \\
\hline \multirow{2}{*}{ Pegmatit $^{1}$} & $\mathrm{Ce}, \mathrm{Nb}, \mathrm{Ta}, \mathrm{Th}, \mathrm{U}, \mathrm{REE}, \mathrm{Li}$, \\
& $\mathrm{Be}, \mathrm{Cs}$ \\
\hline \multirow{2}{*}{ Tipe Carlin $^{2}$} & $\mathrm{Li}, \mathrm{Cu}, \mathrm{Mn}, \mathrm{Ba}, \mathrm{Mo}, \mathrm{Cr}, \mathrm{Co}$, \\
& $\mathrm{Ag}, \mathrm{Cd}, \mathrm{Ni}, \mathrm{Zn}, \mathrm{Pb}$ \\
\hline \multirow{2}{*}{ Epitermal $^{3}$} & $\mathrm{Cu}, \mathrm{Pb}, \mathrm{Zn}, \mathrm{Au}, \mathrm{Sb}, \mathrm{Hg}$, \\
& $\mathrm{Ag}, \mathrm{Se}, \mathrm{Bi}, \mathrm{As}, \mathrm{Mn}$ \\
\hline \multirow{2}{*}{ Ni-Laterit (Supergen) } & \\
& $\mathrm{Ni}, \mathrm{Co}, \mathrm{Mn}, \mathrm{Fe}, \mathrm{Cr}, \mathrm{Al}, \mathrm{Mg}$, \\
& $\mathrm{Si}$
\end{tabular}

keterangan:

${ }^{1}$ Evans, 1993

${ }^{2}$ Nelson, 1990

${ }^{3}$ Levinson, 1980; Suprapto, 2006

${ }^{4}$ Sutisna dkk., 2006

Berdasarkan tabel di atas, maka dapat diinterpretasikan bahwa anomali Zn-Mn(Au)-(As) pada Formasi Mandalika diinterpretasikan terbentuk akibat mineralisasi epitermal. Anomali Ag-Mo-Pb pada Formasi Wonosari diinterpretasikan terbentuk akibat mineralisasi tipe Carlin. Anomali unsur $\mathrm{Cu}$ pada asosiasi $\mathrm{Zn}-\mathrm{Mn}$ (Cu)-(Au)-(As) diinterpretasikan tidak terbentuk akibat mineralisasi epitermal, melainkan terbentuk akibat mineralisasi tipe Carlin yang secara umum berada pada Formasi Wonosari. 
Hal ini dapat dibuktikan dengan Formasi Mandalika yang tersusun atas batuan vulkanik sebagai host rock dalam tipe epitermal dan Formasi Wonosari yang tersusun atas batugamping sebagai host rock dalam tipe Carlin, serta posisi stratigrafi Formasi Mandalika yang lebih tua dari Formasi Wonosari (Gambar 3).

\section{Urutan Kejadian Mineralisasi}

Hubungan antara geokimia dan kondisi geologi daerah penelitian yang telah ditentukan kemudian dikaitkan dengan umur aktivitas magmatik menurut literatur yang ada (Tabel 7). Hal ini dilakukan untuk menginterpretasi urutan kejadian mineralisasi.

Tabel 7. Urutan Kejadian Mineralisasi

\begin{tabular}{cccc}
\hline $\begin{array}{c}\text { Anomali } \\
\text { Unsur }\end{array}$ & $\begin{array}{c}\text { Satuan } \\
\text { Batuan }\end{array}$ & Umur & $\begin{array}{c}\text { Tipe } \\
\text { Mineralisasi }\end{array}$ \\
\hline $\mathrm{Cu}$ & $\begin{array}{c}\text { Formasi } \\
\text { Wonosari }\end{array}$ & $\begin{array}{c}\text { Miosen } \\
\text { Akhir }\end{array}$ & Tipe Carlin \\
\hline $\begin{array}{c}\text { Ag-Mo- } \\
\mathrm{Pb}\end{array}$ & $\begin{array}{c}\text { Formasi } \\
\text { Wonosari }\end{array}$ & $\begin{array}{c}\text { Miosen } \\
\text { Akhir }^{1}\end{array}$ & Tipe Carlin \\
\hline $\begin{array}{c}\mathrm{Zn}-\mathrm{Mn}- \\
(\mathrm{Au})-\end{array}$ & $\begin{array}{c}\text { Formasi } \\
\text { (As) }\end{array}$ & $\begin{array}{c}\text { Miosen } \\
\text { Mwal }^{2}\end{array}$ & Epitermal \\
\hline
\end{tabular}

keterangan:

${ }^{1}$ Widodo dan Simanjuntak, 2002

2Sjarifudin dan Hamidi, 1992

\section{Sintesis Geologi}

Sejarah geologi daerah penelitian diawali dengan aktivitas magmatik pada Oligosen Akhir-Miosen Awal yang menghasilkan material gunungapi berupa lava andesitik, basalt, riolit, dasit, dan tuf membentuk Formasi Mandalika. Hal ini disebabkan oleh penunjaman Lempeng Samudera India-Australia ke bawah Lempeng Benua Eurasia. Kemudian pada Miosen Awal terjadi penurunan diikuti genang laut yang mengendapkan Formasi Campurdarat secara tidak selaras di atas Formasi Mandalika. Selanjutnya terjadi aktivitas pasca magmatik menghasilkan terobosan andesit, dasit, dan tonalit membentuk Satuan Batuan Terobosan yang menerobos Formasi Mandalika dan Formasi Campurdarat (Sjarifudin dan Hamidi, 1992). Hal ini mengakibatkan terjadinya mineralisasi epitermal pada
Formasi Mandalika membentuk anomali $\mathrm{Zn}-\mathrm{Mn}-(\mathrm{Au})-(\mathrm{As})$.

Pada Miosen Tengah-Miosen Akhir terjadi pengendapan Formasi Nampol diikuti Formasi Wonosari pada lingkungan laut dangkal (zona neritik) yang tersusun atas batugamping mudstone, wackestone, boundstone, dan kalsilutit (Sjarifudin dan Hamidi, 1992). Kemudian terjadi mineralisasi tipe Carlin pada Formasi Wonosari membentuk anomali Ag-Mo-Pb (Widodo dan Simanjuntak, 2002). Anomali unsur $\mathrm{Cu}$ pada Formasi Wonosari diinterpretasikan terbentuk akibat peristiwa mineralisasi yang serupa tetapi terbentuk setelah anomali unsur Ag-Mo$\mathrm{Pb}$ pada Miosen Akhir.

\section{Area Prospek}

Area prospek merupakan area yang diinterpretasikan mempunyai potensi ekonomis mineralisasi logam. Delineasi area prospek ditentukan berdasarkan peta persebaran anomali unsur dengan cara menelusuri bagian hulu sungai dari titik lokasi conto yang memiliki nilai anomali. Hulu sungai yang telah ditelusuri kemudian dibatasi oleh daerah aliran sungai (DAS) sehingga diperoleh delineasi area prospek.

Pada penelitian ini terdapat 14 area prospek yang diurutkan tingkat keekonomisannya berdasarkan besarnya nilai anomali unsur dan banyaknya unsur yang memiliki nilai anomali dalam suatu asosiasi. Tabel 8 menunjukkan area prospek di daerah penelitian yang diurutkan berdasarkan tingkat keekonomiannya. Area A merupakan area potensial dengan tingkat keekonomian paling tinggi dan sebaliknya area $\mathrm{N}$ merupakan area potensial dengan tingkat keekonomian paling rendah. Peta area prospek dapat dilihat pada Gambar 6.

Area prospek yang telah ditentukan dapat digunakan sebagai rujukan untuk penelitian tahap penyelidikan geokimia selanjutnya. Penyelidikan geokimia rinci dapat dilakukan pada area potensial untuk 


\section{MAKALAH ILMIAH}

menentukan lokasi tubuh bijih.

Tabel 8. Area Prospek Logam

\begin{tabular}{|c|c|c|c|c|c|c|}
\hline \multirow{2}{*}{$\begin{array}{c}\text { Area } \\
\text { Prospek }\end{array}$} & \multicolumn{2}{|c|}{ Koordinat Area } & \multirow{2}{*}{ Asosiasi Unsur } & \multirow{2}{*}{$\begin{array}{c}\text { Tipe } \\
\text { Mineralisasi }\end{array}$} & \multirow{2}{*}{ Satuan Batuan } & \multirow{2}{*}{ Lokasi } \\
\hline & $X(\mathrm{mT})$ & $Y(m U)$ & & & & \\
\hline $\mathrm{A}$ & 620449 & 9090890 & Ag-Mo-Pb & Tipe Carlin & Formasi Wonosari & Ngrejo \\
\hline$B$ & 623100 & 9085860 & $\mathrm{Ag}-\mathrm{Mo}-\mathrm{Pb}$ & Tipe Carlin & Formasi Wonosari & Pasiraman \\
\hline $\mathrm{C}$ & 625818 & 9092430 & Zn-Mn-(Au)-(As) & Epitermal & Formasi Mandalika & Sumberwaringin \\
\hline $\mathrm{D}$ & 631643 & 9091560 & Zn-Mn-(Au)-(As) & Epitermal & Formasi Mandalika & Kepek \\
\hline $\mathrm{E}$ & 632574 & 9093400 & $\mathrm{Zn}-\mathrm{Mn}-(\mathrm{Au})-(\mathrm{As})$ & Epitermal & Formasi Mandalika & Kepek \\
\hline $\mathrm{F}$ & 629158 & 9087820 & Zn-Mn-(Au)-(As) & Epitermal & Formasi Mandalika & Sumberboto \\
\hline G & 625365 & 9086740 & Zn-Mn-(Au)-(As) & Epitermal & Formasi Mandalika & Sumberboto \\
\hline $\mathrm{H}$ & 622559 & 9081410 & $\mathrm{Ag}-\mathrm{Mo}-\mathrm{Pb}$ & Tipe Carlin & Formasi Wonosari & Kalibawang \\
\hline I & 624272 & 9085010 & $\mathrm{Ag}-\mathrm{Mo}-\mathrm{Pb}$ & Tipe Carlin & Formasi Wonosari & Pasiraman \\
\hline $\mathrm{J}$ & 627529 & 9084360 & $\mathrm{Ag}-\mathrm{Mo}-\mathrm{Pb}$ & Tipe Carlin & Formasi Wonosari & Centung \\
\hline $\mathrm{K}$ & 625190 & 9083150 & $\mathrm{Ag}-\mathrm{Mo}-\mathrm{Pb}$ & Tipe Carlin & Formasi Wonosari & Centung \\
\hline $\mathrm{L}$ & 631918 & 9083000 & $\mathrm{Ag}-\mathrm{Mo}-\mathrm{Pb}$ & Tipe Carlin & Formasi Wonosari & Besole \\
\hline $\mathrm{M}$ & 631918 & 9089720 & $\mathrm{Ag}-\mathrm{Mo}-\mathrm{Pb}$ & Tipe Carlin & Formasi Wonosari & Sumberglagah \\
\hline $\mathrm{N}$ & 626719 & 9082600 & $\mathrm{Cu}$ & Tipe Carlin & Formasi Wonosari & Centung \\
\hline
\end{tabular}

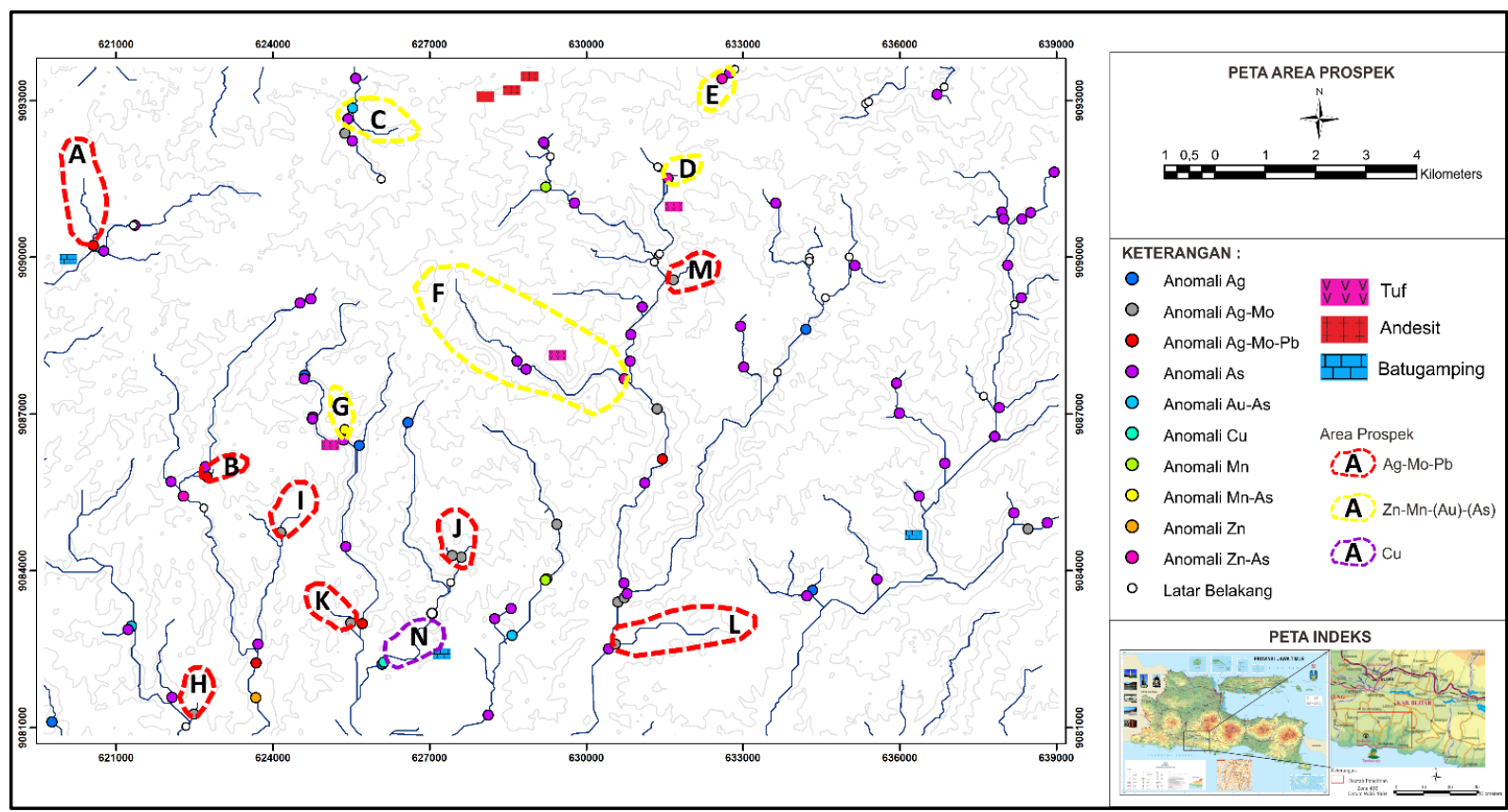

Gambar 6. Peta Area Prospek

\section{KESIMPULAN}

Anomali $\mathrm{Zn}-\mathrm{Mn}-(\mathrm{Au})-(\mathrm{As})$ pada Formasi Mandalika diinterpretasikan terbentuk akibat mineralisasi epitermal. Anomali Ag$\mathrm{Mo}-\mathrm{Pb}$ pada Formasi Wonosari diinterpretasikan terbentuk akibat mineralisasi tipe Carlin. Anomali unsur $\mathrm{Cu}$ pada Formasi Wonosari kemungkinan terbentuk akibat peristiwa mineralisasi tipe Carlin dalam rentang waktu Miosen Akhir tetapi anomali Ag-Mo-Pb terbentuk terlebih dahulu dibandingkan anomali $\mathrm{Cu}$.

Potensi area prospek mineralisasi logam di daerah penelitian dapat dibagi menjadi
14 area, yaitu area prospek $\mathrm{Ag}-\mathrm{Mo}-\mathrm{Pb}$ yang terletak di hulu sungai pada daerah Ngrejo, Pasiraman, Kalibawang, Centung, Besole, dan Sumberglagah; area prospek $\mathrm{Zn}-\mathrm{Mn}-(\mathrm{Au})-(\mathrm{As})$ yang terletak di hulu sungai pada daerah Sumberboto, Kepek, dan Sumberwringin; serta area prospek $\mathrm{Cu}$ yang terletak pada sungai di daerah Centung.

\section{UCAPAN TERIMAKASIH}

Penulis mengucapkan terima kasih kepada Kepala Pusat Sumber Daya Mineral, Batubara dan Panas Bumi, Kepala Bidang Mineral, Kepala Subbidang 
Mineral Logam, serta semua pihak yang telah membantu dalam pembuatan tulisan ini.

\section{DAFTAR PUSTAKA}

Anonim (2003) : Badan Koordinasi Survei dan Pemetaan Nasional, Provinsi Jawa Timur.

Darman, H. dan Sidi, F.H. (2000): An Outline of The Geology Indonesia, Ikatan Ahli Geologi Indonesia.

Evans, A.M. (1993): Ore Geology and Industrial Minerals an Introduction. Edisi Ketiga. Blackwell Scientific Publications, London.

Howard, A. D. (1967): Drainage analysis in geologic interpretation: a summation. AAPG bulletin, 51(11), 2246-2259.

Karypis, G., Han, E., dan Kumar, V. (1999): Chameleon: hierarchical clustering using dynamic modeling. IEEE Computer, Vol. 32, Issue 8, Aug 1999.

Levinson, A.A. (1980): Introduction to Exploration Geochemistry. Edisi Kedua. Applied Publishing, Illinois.

Nelson, C.E., 1990. Comparative geochemistry of jasperoids from Carlin type gold deposits of The Western United States. In: J.W. Hedenquist, N.C. White and G. Siddeley (Editors), Epithermal gold mineralization of The Circum Pacific: Geology, geochemistry, origin and exploration, II. Journal of Geochemical Exploration 36: 171195.

Rose, A.W., Hawkes, H.E., dan Webb, J.S. (1979): Geochemistry in Mineral Exploration. Edisi Kedua. Academic Press, London.

Sinclair, A.J. (1987): Statistical Interpretation of Soil Geochemical Data, Exploration, The Association of Exploration Geochemists, Vol. 4.
Sjarifudin, M.Z. dan Hamidi, S. (1992): Geologi Lembar Blitar, Jawa skala 1:100.000, Pusat Penelitian dan Pengembangan Geologi, Bandung.

Suprapto, S. J. (2006): Geokimia regional Sulawesi bagian Utara percontoh endapan sungai aktif-80 mesh. Indonesian Journal on Geoscience, 1(2), 73-82.

Surjadi, P.A. (1976): Pendahuluan Teori Kemungkinan dan Statistika. Penerbit ITB, Bandung.

Suroto, M.I. (2005): Prospeksi geokimia berdasarkan analisis statistik data konsentrasi conto endapan sungai aktif dan konsentrat dulang di daerah Sungai Mentebah dan sekitarnya, Kalimantan Barat, Program Studi Teknik Geologi, Fakultas IImu dan Teknologi Kebumian, Institut Teknologi Bandung, Bandung.

Sutisna, D.T., Sunuhadi, D.N., Pujobroto, A., dan Herman, D.Z. (2006): Perencanaan eksplorasi cebakan nikel laterit di daerah Wayamli, Teluk Buli, Halmahera Timur sebagai model perencanaan eksplorasi cebakan nikel laterit di Indonesia. Buletin Sumberdaya Geologi, Vol.1 Nomor 3, hlm. 48-56.

van Bemmelen, R.W. (1949): General Geology of Indonesia and Adjecent Archipelagoes, The Hague, Martinus Nijhoff, Vol. 1A, Netherlands.

Widodo, W., \& Simanjuntak, S. (2002). Hasil Kegiatan Eksplorasi Mineral Logam Kerjasaman Teknik Asing Daerah Pegunungan Selatan Jawa Timur (JICA/MMAJ-Jepang) dan Cianjur (KIGAM-Korea). Kolokium Direktorat Inventarisasi Sumber Daya Mineral (DIM) TA.2002.

\begin{tabular}{ll|}
\hline Diterima & $:$ 27 September 2019 \\
Direvisi & $:$ 28 Oktober 2019 \\
Disetujui & $:$ 30 November 2019
\end{tabular}

